Article

\title{
Missing in Action? France and the Politicization of Trade and Investment Agreements
}

\author{
Sophie Meunier ${ }^{1, *}$ and Christilla Roederer-Rynning ${ }^{2}$ \\ ${ }^{1}$ Woodrow Wilson School of Public and International Affairs, Princeton University, Princeton, NJ 08544, USA; \\ E-Mail: smeunier@princeton.edu \\ 2 Department of Political Science and Public Management, University of Southern Denmark, 5000 Odense, Denmark; \\ E-Mail: crr@sam.sdu.dk \\ * Corresponding author
}

Submitted: 4 November 2019 | Accepted: 7 February 2020 | Published: 31 March 2020

\begin{abstract}
Negotiations for the Transatlantic Trade and Investment Partnership (TTIP) between the European Union (EU) and the United States (US) and for the Comprehensive Economic and Trade Agreement (CETA) between the EU and Canada have provoked massive mobilization throughout Europe, both on the streets and online. Yet France, long at the epicenter of anti-globalization and anti-Americanism, has played a surprisingly modest role in the mobilization campaign against these agreements. This article asks why France did not contribute to anti-TTIP mobilization and, more broadly, how patterns of French mobilization over trade have changed over the past two decades. Using comparative-historical analysis, we explore to what extent this puzzling French reaction can be traced to changing attitudes towards the US, agenda-shaping by the French government, and transformations in the venues and techniques of social mobilization. We thus contribute to the growing literature on the politicization of trade agreements and offer insights into the links between domestic and international politics.
\end{abstract}

\section{Keywords}

Common Commercial Policy; Comprehensive Economic and Trade Agreement; European Union; France; investment; multilateral investment agreement; politicization; trade; Transatlantic Trade and Investment Partnership

Issue

This article is part of the issue "Politicization of EU Trade Policy across Time and Space" edited by Dirk De Bièvre (University of Antwerp, Belgium), Oriol Costa (Universitat Autònoma de Barcelona, Spain/IBEI, Spain), Leif Johan Eliasson (East Stroudsburg University, USA) and Patricia Garcia-Duran (University of Barcelona, Spain).

(C) 2020 by the authors; licensee Cogitatio (Lisbon, Portugal). This article is licensed under a Creative Commons Attribution 4.0 International License (CC BY).

\section{Introduction}

Over the past decade, several trade and investment agreements negotiated by the European Union (EU) have drawn massive protests both on the street and online, especially during negotiations for the Transatlantic Trade and Investment Partnership (TTIP) with the United States (US), and the Comprehensive Economic and Trade Agreement (CETA) with Canada. This development has spawned scholarly interest in the politicization of European trade policy. Some scholars have pointed to a broader pattern of politicization in the EU, defined as increasing polarization of opinions and public salience (De Bruycker, 2017; de Wilde, 2011; Schimmelfennig, Leuffen, \& Rittberger, 2015). Others have focused on explaining why trade policy became politicized after decades of relative public obscurity (De Bièvre \& Poletti, 2017; Eliasson \& Garcia-Duran Huet, 2019; Laursen \& Roederer-Rynning, 2017; Young, 2017). Others yet have emphasized variation in the degree of politicization over time, and across agreements and countries (De Bièvre \& Poletti, 2019; Meunier \& Czesana, 2019; Young, 2019). 
This article adds to this recent focus on variation in politicization by tackling an intriguing paradox in the politics of contestation of recent trade and investment agreements. The TTIP and CETA negotiations have been the subject of massive public protests throughout the EU, eliciting levels of contestation arguably not seen since the 1930s (Donnan, 2016). At the height of contestation, in 2015, more than 3.2 million Europeans had signed the 'STOP TTIP!' petition aimed at pulling the EU out of the TTIP negotiations (Euractiv, 2015). Demonstrations in 2015 and 2016 brought hundreds of thousands into the streets throughout the EU, with a particular concentration of protesters in Germany (Deckstein, Salden, \& Schießl, 2016). Yet the voice of French protesters, traditionally one of the loudest and fiercest countries in denouncing globalization, has been conspicuously absent.

How important was France in the European antiTTIP mobilization campaign? Why did France play such a surprisingly modest role? This pattern of muted French mobilization in a context of heightened contestation in Europe is puzzling for several reasons. France has a culture of protest. It also has a history of strong anti-globalization mobilization, particularly in the late 1990s. Finally, France is notoriously anti-American. One would therefore expect France to have spearheaded anti-TTIP and anti-CETA mobilization, yet it did not. Our aim in this article is to map out patterns of French mobilization against global trade deals like TTIP and CETA, and to develop potential explanations for these patterns. Using comparative-historical analysis, we explore this puzzle in light of prior patterns of dynamics of social mobilization, governmental strategies, and societal anti-Americanism.

The article is structured as follows. First, we discuss the argument of France as a leading actor in the global mobilization against trade and investment agreements in the 1990s - the Multilateral Agreement on Investment (MAI) between 1995 and 1998, and the failed Seattle Millennium Round of the World Trade Organization (WTO) in 1999. Second, we present puzzling findings on French public contestation on TTIP and show, through comparative analysis, that France was 'missing in action' (MIA) in extra-institutional arenas of politicization, while other countries led the contestation. Finally, we advance a range of possible explanations, which we probe in greater detail in a within-case analysis of TTIP politicization in France.

\section{France as the Epicenter of Anti-Globalization Contestation: The Critical Juncture of the late 1990s}

To grasp recent changing patterns of global trade politics and the role of France in anti-globalization mobilization, we must go back to the late 1990s, when a new, and more constraining, multilateral trade system emerged around the creation of the WTO. France found itself at the center of both the shaping of this new order and its contestation.
Two important developments took place in the 1990s. One was the deepening of the trade liberalization agenda. With the Uruguay Round of negotiations (1986-1994), the General Agreement on Tariffs and Trade took on 'behind the border' trade issues (Young \& Peterson, 2006); subsequently, this new 'deep trade' agenda extended to a variety of economic sectors and regulations, including services, competition policy, environmental standards, labor rights, and investment. The other development was the growing involvement of non-governmental organizations (NGOs) in global trade politics. "Before the 1990s," as Graham (2000) argues, "the world of the environmentally oriented NGOs and the world of international trade and investment agreements were essentially disjoint. They coexisted, but they did not touch or overlap to any significant degree" (p. 35). This all changed in the 1990s when NGOs engaged in the negotiations of the NAFTA (North American Free Trade Agreement), ratified in 1993 by the US, Canada and Mexico, before shifting their focus to the global level, where all these 'new' trade issues were being discussed (Deslauriers \& Kotschwar, 2003).

This new NGO activism interacted with the deep trade' agenda during negotiations for the MAI, launched in May 1995 under the aegis of the OECD (Organisation for Economic Co-operation and Development). The agreement aimed to provide an institutional framework for international investment, which, unlike trade, lacked any formal multilateral rules. The negotiations started outside of the public glare, but very soon turned into the first public mobilization against globalization of the new global era. In February 1997, an early draft of the MAl was leaked to Public Citizen, a rights advocacy NGO, and published online, stirring opposition from more than 600 organizations in almost 70 countries, from labor groups to environmental activists (Kobrin, 1998; Walter, 2001). The opposition reflected a general anxiety about globalization, with a particular focus on the political power of large multinational corporations; namely, the capacity of multinational corporations to sue sovereign governments for democratically agreed upon laws and policies through Investor-State Dispute Settlement (ISDS) systems.

While opposition to the MAI was multinational, there is broad acknowledgment in the literature that France played a pivotal role in its demise (Waters, 2004). We argue that France was at the epicenter of the contestation as a result of three key factors.

\subsection{Culture at the Heart of the Contestation}

Though the agreement was multifaceted and covered a whole range of economic sectors, opposition to the MAl focused on culture in particular. By addressing non-discriminatory treatment for foreign investors in all sectors, the MAI negotiations extended to cultural goods and services-a vigorous and popular sector of the French economy and an essential component of 
the French identity. Culture became the focal point of French opposition, and led to mobilization of intellectual and political elites across the ideological spectrum. Philippe Seguin, head of the Rassemblement pour la République party, claimed that integrating cultural goods and services into the MAI negotiations "would be the eventual death of our cinematic culture" (Tartaglione, 1998). Hervé Bourges, president of the French media regulator (Conseil Supérieur de l'Audiovisuel), argued that Europeans should "oppose the colonization of new media by a lone language-English-and by a lone inspiration - that of international groups" (Tartaglione, 1998). Both left-wing and right-wing politicians denounced globalization as the death knell of French culture and demanded a carve-out for cultural industries (Gordon \& Meunier, 2001).

\subsection{Traditional French Anti-Americanism}

The 'cultural exception' met a fertile anti-American sentiment in France. A portion of opposition to the agreement came from sheer nationalism. As an anti-MAl activist conceded at the time:

Some of the objections [raised by the French government] are clearly based on nationalist grounds: France has always had an uneasy relationship with the US, and many of the objections to the measures are simple assertions of national sovereignty versus powerful, and implicitly US, economic interests. (Wood, 2000, p. 38)

The MAl was expected to benefit American multinational corporations more than others since the negotiating agenda had been driven by American business lobbies (Walter, 2001). Anti-globalization in France thus became inextricably tied to anti-Americanism (Meunier, 2000). Given the pervasiveness of the equation between globalization and Americanization in French society (Meunier, 2006), Alons and Giacalone (2014) argued that antiAmericanism is potentially more powerful than any other domestic factor in shaping French responses to globalization because it was "less prone to wax and wane with domestic political changes" than in other societies (p. 150).

\subsection{Political Entrepreneurship}

During the MAI negotiations French politics was dominated by 'cohabitation,' or divided government. President Jacques Chirac, of the rightwing Rassemblement pour la République, had called for legislative elections in 1997, which delivered an unexpected victory to the Socialist Party. The new 'Plural Left' government, under the leadership of socialist Prime Minister Lionel Jospin, represented a fragile mix of Socialists, Communists and Greens. Opposition to the MAI was a rare point of consensus in divided French politics: the Socialists denounced threats to labor rights, the
Communists denounced the expansion of capitalism to all walks-of-life, the Greens denounced the dangers to the environment posed by the agreement, while politicians from the right denounced threats to national sovereignty and French cultural identity.

The French government therefore catered to opposition to the MAI to cement its coalition (Graham, 2000, p. 11). It suspended negotiations in April 1998 after imposing conditions that nobody expected to be met: the exclusion of cultural goods and services from the agreement, the non-extension of US law outside of US territory, special consideration for the process of European integration, and the inclusion of environmental and social norms in the agreement. The government also commissioned a report that highlighted the discrepancies between technocratic and political imperatives in the negotiation of the agreement, and the imbalance of the negotiations in favor of US business interests (Lalumiere \& Landau, 1998). France officially withdrew from the negotiations in October 1998, leading to their collapse in December, and suggested a change of venue, such as the WTO, to address investment concerns.

Opposition by the French government developed in parallel to the 'alter-globalization' activism of French movement entrepreneurs. France was a hotbed of intellectual criticism of neo-liberal globalization, partly spearheaded by a group of activists around the emerging anti-globalization organization ATTAC (Association pour une taxation des transactions financières pour l'aide aux citoyens). Originating as a critique of global financial capitalism in the pages of the Monde Diplomatique newspaper, ATTAC quickly captured the attention of politicians and citizens, prompting the French National Assembly (Assemblée Nationale) in 2001 to support the introduction of a Tobin tax on financial transactions. ATTAC was also the first successful alliance between the cultural sector and other segments of French society, including trade unions and small farmers. One such farmer, the charismatic José Bové, was a founder of ATTAC, and of the peasant union Confédération Paysanne a decade earlier. With his Asterix-like moustache, and flair for attracting media attention, the English-fluent sheep farmer trade unionist became famous in France, and beyond, after leading the 'dismantling' of construction for a McDonald's restaurant in central France in 1999 (Meunier, 2000). Four years after its creation, ATTAC had spawned forty sister organizations throughout the world. Besides being able to deliver a strong, specific, and credible analysis of globalization and its alternative (Ancelovici, 2002, p. 444), ATTAC's power resided in the use of transnational social media, which enabled it to recruit and mobilize individuals widely (Kolb, 2005).

While anti-trade mobilization in France traditionally revolved around farmers' protest (Alons, 2014; RoedererRynning, 2002, 2007; van der Vleuten \& Alons, 2012), after the collapse of negotiations for the MAl, and the emergence of ATTAC, it brought together new and classic grievances. Collectively, the inclusion of cultural goods 
on the negotiation agenda, anti-Americanism, and political entrepreneurship explain why France displayed higher and more intense levels of anti-globalization mobilization in the late 1990s. The defeat of the MAl marked the crystallization of a broad anti-globalization camp in France, spanning both state and non-state spheres.

\section{From MAI to MIA? Puzzling Patterns of TTIP-Related Politicization in France and the EU}

The fifteen years following the demise of the MAl in 1998, and the aborted launch of the WTO's Millenium Round in Seattle in 1999, were a period of relative calm for anti-globalization and anti-trade activism in France and in Europe. These years were also marked by the conclusion of many multilateral and bilateral trade and investment negotiations: with South Korea, Singapore, India, ASEAN countries, and Canada. The TTIP broke that period of relative calm. From its inception in 2013 to its suspension in 2017, the TTIP met broad public contestation on both sides of the Atlantic, but especially in Europe (De Ville \& Siles-Brügge, 2015; Young, 2017). The TTIP had all the ingredients of a perfect storm, prone to reactivate the triggers of French mobilization in the 1990s: the most ambitious agenda of trade and investment negotiations in the post-Cold War era; the opportunity for political entrepreneurs to rally a divided French public across the political spectrum; and the US as a key party to the negotiation, supported by its multinational companies. These features make the TTIP a most-likely case of French contention, yet opposition failed to arise.

\subsection{The Indifferent French}

Public opposition to the TTIP picked up pace during the Spring of 2014, in the run-up to the elections to the
European Parliament (Buonanno, 2015; Young, 2017). Surprisingly, Europeans were more positive towards the TTIP than their US counterparts (Bluth, 2016), and they remained in majority in favour of such an agreement throughout the 2014-2016 period. However, public support in the EU as a whole clearly eroded over the period, and there were critical national differences (Figures 1 and 2).

In all but three EU member states, Europeans by and large favoured a free trade and investment agreement between the EU and the US. These supportive member states included France. An opinion poll carried out by the French Institut CSA between 14 and 16 May 2014 showed two surprising results. First, a very large majority of respondents favoured the proposed harmonization of production norms and standards (71\%), and the removal of tariffs and customs duties (68\%; CSA, 2014, p. 4). Secondly, the TTIP was not a very salient issue. One year into the TTIP negotiations, the majority of respondents (55\%) had still not heard about them; and among those who had, $28 \%$ admitted having only a very vague notion of what the TTIP was (CSA, 2014, p. 4). At the height of the TTIP public controversy, in 2015, only 1 in 5 French respondents reported following the TTIP negotiations 'closely' or 'very closely' - compared to 1 in 3 in neighbouring Germany (YouGov, 2015).

Beyond these two unexpected findings, French public opinion on the left was more sceptical, but divided. Those close to Jean-Luc Mélenchon's left-wing party Front de Gauche were more markedly against the removal of tariffs and customs duties: $57 \%$ were against, compared to $55 \%$ of those who sympathized with green movements who supported the harmonization of norms and standards. Thus, beyond a more activist left partisan base, the French as a whole did not appear to be very interested or outraged.

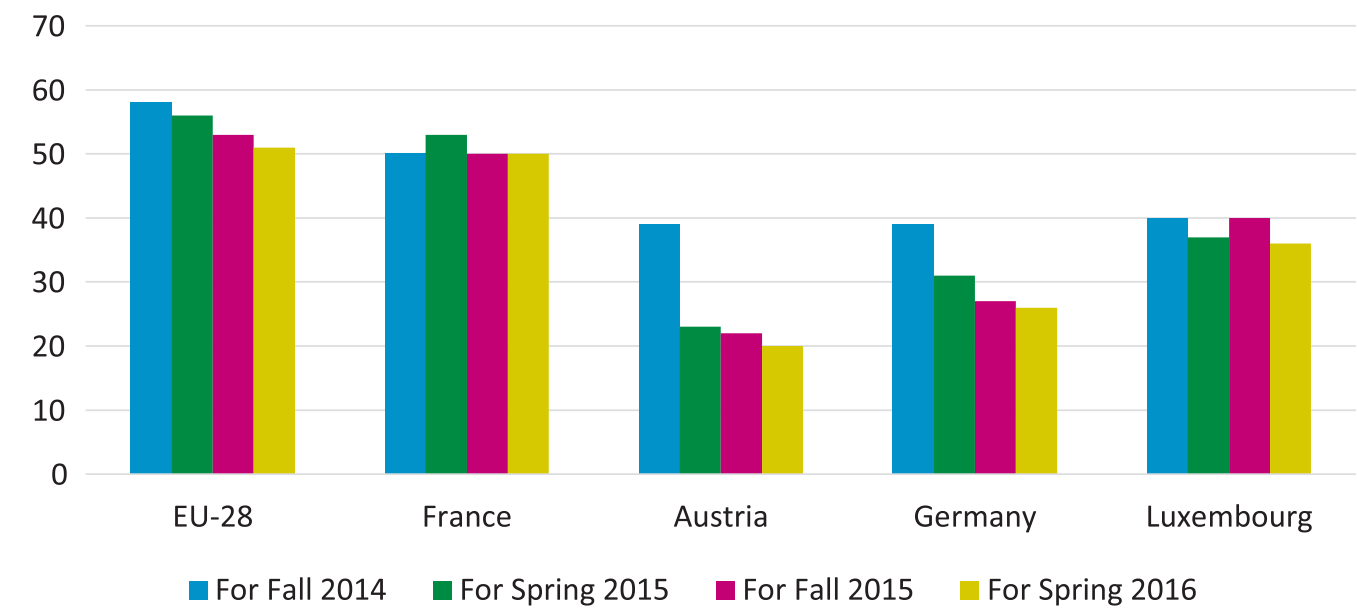

Figure 1. Public support for a free trade and investment agreement between the EU and the US, 2014-2016 (\% in favour). Source: Eurobarometer (2014, 2015a, 2015b, 2016). Note: Eurobarometers started polling Europeans on the TTIP in the spring 2014 (question A19.5 in Eurobarometer 82, and related numbers in the following surveys: "What is your opinion on each of the following statements. Please tell me for each of the following statement whether you are for it or against it: A free trade and investment agreement between the EU and the US.") 


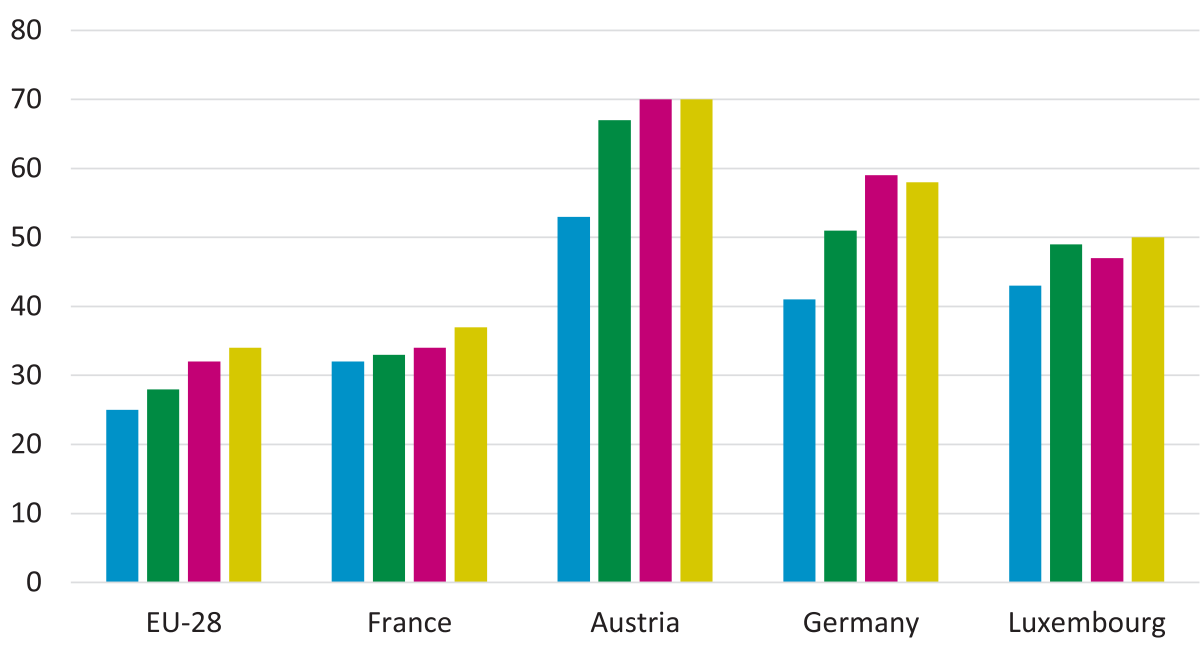

n Against Fall 2014 against Spring 2015 against Fall 2015 Against Spring 2016

Figure 2. Public support for a free trade and investment agreement between the EU and the US, 2014-2016 (\% against). Source: Eurobarometer (2014, 2015a, 2015b, 2016).

This stood in stark contrast with responses in Austria, Germany, and Luxembourg, where a public opinion tsunami materialized against the TTIP. Germany surprised observers - and itself-by the intensity of its antiTTIP public opposition given the country's traditionally pro-free trade positions. From the beginning, the TTIP drew more opposition than support in Germany, where opposition grew from $41 \%$ in fall 2014 to $59 \%$ in spring 2016, suggesting a broad-based, cross-partisan opposition. In April 2015, as TTIP support had shrunk to $25 \%$ in German public opinion, observers noted a:

Level of resistance [that] has taken Chancellor Angela Merkel's government and German industry by surprise, [which] are now scrambling to reverse the tide and save a deal which proponents say could add $\$ 100$ billion in annual economic output on both sides of the Atlantic. (Barkin, 2015)

One year later, the country's leaders had adopted a more cautionary approach, recognizing that:

[The] TTIP has run into huge opposition in Germany....It is a paradox that public opinion in Europe's biggest exporter-and one of the greatest beneficiaries of global trade-is running so strongly against TTIP. Even senior German officials scratch their heads at the debate. (Wagstyl, 2016)

These preliminary findings on public opinion suggest that, breaking with the history of the previous decade, it was in Germany that opposition to the TTIP was fiercest; and it was mostly German-not French-opposition, which forced EU leaders to reconsider their advocacy of the TTIP.

Even so, the contrast between German and French publics should not be overstated. French public opin- ion grew increasingly incandescent over time. In June 2016, 62\% of French respondents allegedly opposed the 'transatlantic trade agreements' (TTIP and CETA) (Vu de France, 2016). According to some of policymakers, it would have taken little for French opposition to the TTIP to take off like a bonfire. Next, we consider the pattern of European anti-TTIP activism in greater detail.

\subsection{The Contentious Germans}

Social mobilization against TTIP in Europe was intense, broad, and durable. It was also full of national contrasts. Social mobilization started at the time of inception for the TTIP negotiations, in the Spring of 2013. It maintained steam until the negotiations were suspended in November 2016 (Bouza \& Oleart, 2018, p. 88). Civil society critics of the TTIP coalesced around the European 'STOP TTIP!' campaign, a civil society mobilization framed as a European citizenship initiative to invite the Commission to recommend to the Council to stop TTIP negotiations. The initiative tested the limits of the Lisbon European Citizenship Initiative, which was meant to give EU citizens a voice on EU legislation, not international agreements.

The data we have about the 'STOP TTIP!' campaign sheds interesting light on the involvement of French activists. On one hand, the campaign, launched in February 2014, met a certain success judging by the map of French territorial collectivities, which declared themselves 'hors TAFTA' or 'en vigilance' (TTIP was also initially called the Transatlantic Free Trade Agreement [TAFTA], hence the use of both labels by groups opposed to the proposed US-EU trade and investment agreement) (Figure 3).

Yet, support in France trailed behind other countries. While the 'STOP TTIP!' campaign recorded 3 million signatures in 23 member states, nearly half of the signatures were collected in Germany alone, making it the new epi- 


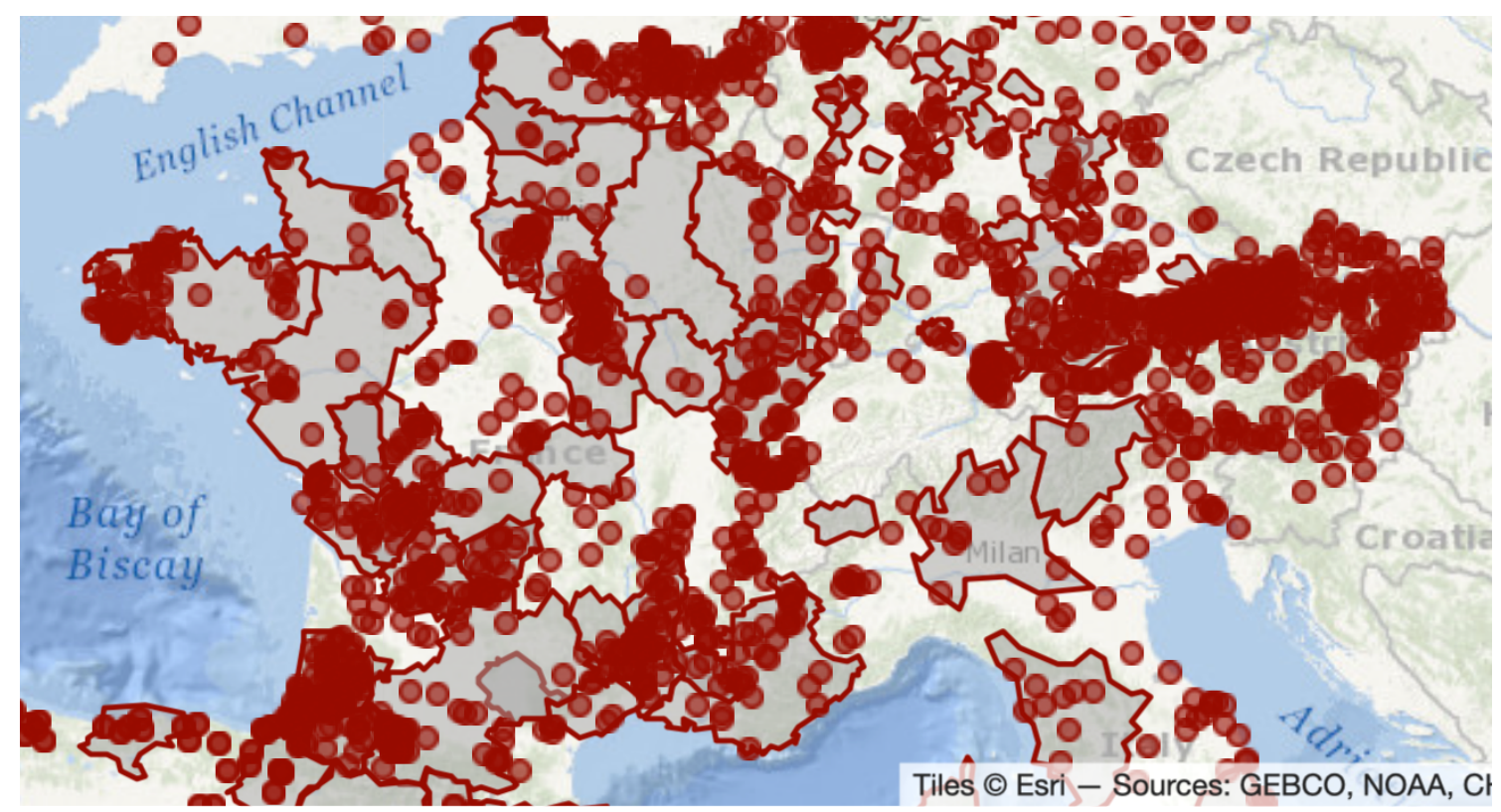

Figure 3. TTIP and CETA free zones in Europe. Source: TTIP Free Zones (n.d.). Note: In France, this movement concerned 840 territorial collectivities, of which there are: 14 regions (out of 22 before 2016), and 24 out of the 95 metropolitan départements.

center of contention. France ranked third (after the UK), far behind Germany with only one tenth of the overall number of signatures (Young, 2017).

Germany was the new epicenter of anti-globalization mobilization (Figure 4). During the critical 2014-2016 period, Germany accounted for $30 \%$ of all TTIP-related actions - far ahead of France, with only $12 \%$ of all-TTIP related actions, but also ahead of (smaller) Austria and Italy (16\% each). As the numbers show, the difference between Germany and France cannot be explained by population differences alone. Furthermore, France was the only country, for which there are data, where the level of social mobilization in 2016 was lower than in 2014. This overarching picture of tepid engagement appears to match anti-TTIP activists' selfreporting (Fabry, 2015). During the transnational mobilizations organized on 18 April 2015, out of 700 events expected to take place, more than 200 occurred in Germany, with 23,000 marching in protest in Munich alone, whereas the French 'Stop-TAFTA' mentioned only 70 events (Mobilisations, 2016).

Thus, while an important site of anti-TTIP mobilization, France no longer seemed to be the epicenter of European contestation, as in past decades. French activists were trailing or even MIA, especially in comparison with their German counterparts. The French were

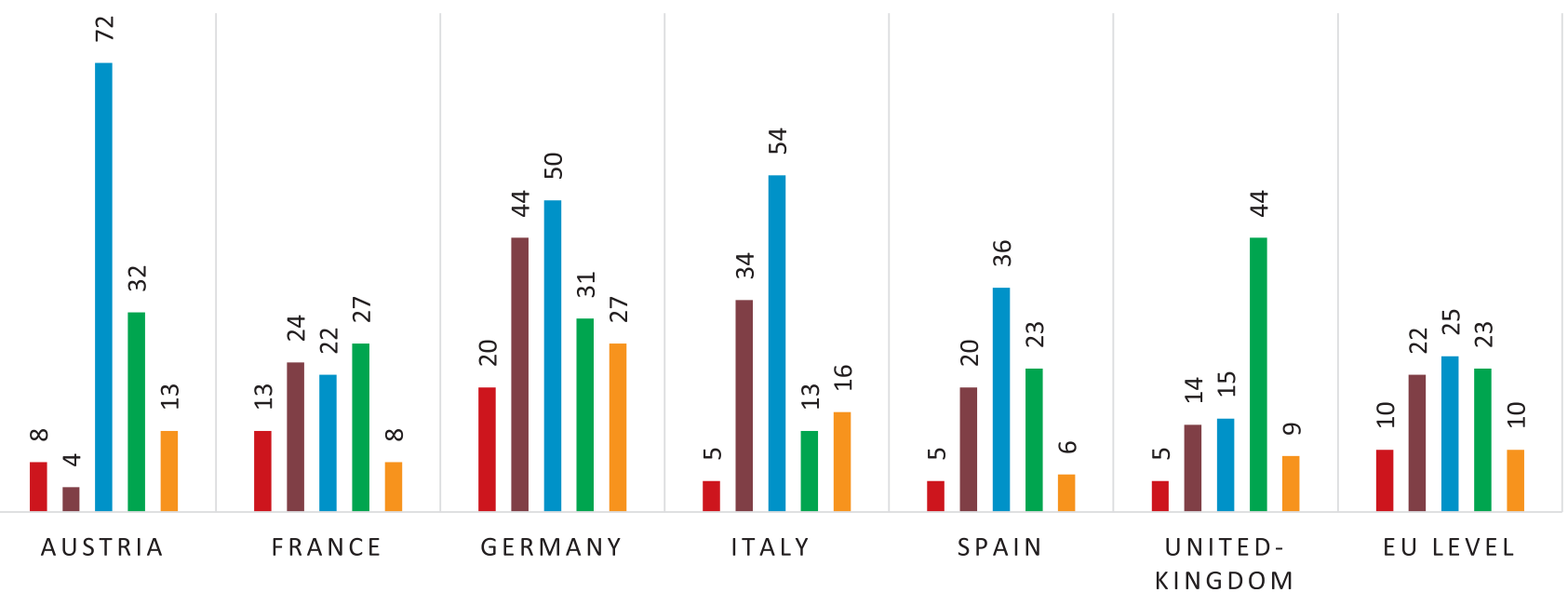

Figure 4. Trends in the social mobilization against TTIP in Europe, by country 2014-2016 (number of protest events). Source: Caiani and Graziano (2018). 
less aware of the TTIP than their German neighbours; to the extent that they were, they were less opposed to the TTIP than their German counterparts. Likewise, anti-TTIP social mobilization was less sustained in France than in Germany. As Fabry noted in 2015, "One was expecting opposition to TTIP to come first from France, where public opinion is traditionally reticent to trade opening. Yet by November 2014...Germans had taken the lead in opposing TTIP" (Fabry, 2015). Against all expectations, the perfect storm of the TTIP abated in France. Why was France MIA?

\section{A Political Process Explanation}

One possibility is that the TTIP failed to trigger reflexive anti-Americanism and street protests because it was a good deal for the French. After all, the French economy was weaker than Germany's, and the TTIP promised to open new lucrative markets for key sectors of the economy while not threatening vested interests. Economic studies suggested that the TTIP would benefit key sectors of the French economy. Potential 'winners' of the TTIP were transportation manufacturing sectors (equipment, machinery, and services), chemicals and pharmaceuticals, and agriculture (World Trade Institute, 2016). Perhaps this particular mix of economic gains explains the more positive reception of the negotiations in France?

We doubt it. Apart from agriculture, the sectors identified as potential winners from TTIP were never at the center of popular mobilization in France. As for agriculture, the French had both offensive and defensive interests in the TTIP, and agriculture as a whole was a contentious topic in the EU-US trade negotiations that resumed in 2018-with the EU (and the French) preferring to keep it off the agenda against US insistence to the contrary. Maybe some agricultural sectors stood to gain from the TTIP, but these winners were likely never involved in the earlier anti-globalization mobilization waves in France.

Besides, the expected gains were arguably more than offset in the public discourse by the potential risks of a downward regulatory convergence in a range of areas salient for the broader public. As Pascal Lamy, the former EU trade commissioner and former Director General of the WTO, put it at the time, these negotiations were "no longer about removing protections; they [were] about harmonising precautions that prevent harm to consumers" (Lamy, 2014). Regulatory risks, perceived or real, spanned the environmental (fracking), health, sanitary and phyto-sanitary (chlorinated chicken, genetically modified organisms) and geographic indicators (Appellations d'origine contrôlées) areas-not to mention the controversial ISDS. They were broadly mediatized by activists, which may explain why public support for the TTIP in France was mixed with a lingering sense of distrust and scepticism.
Finally, culture, the focal point of contention in the late 1990s MAI negotiations, was from the outset an object of controversy in the French TTIP debate-again. Thus, while it is doubtful that economic calculi can elucidate why France was MIA, we must explain why similar issues as those arising in the 1990s failed to produce similar outcomes in the 2010s. Elaborating on our explanation of French contentiousness in the 1990s, we advance a political process explanation for the French MIA puzzle, pinpointing the role of political actorsboth institutional and societal-in defusing reflexive anti-Americanism.

\subsection{Swapping Places-France, Germany, and Anti-Americanism}

France was no longer a beacon of anti-Americanism when the TTIP negotiations took place. This reflected both the softening of anti-Americanism in France and the emergence of German anti-Americanism. Two phenomena explain these changing attitudes towards the US. One, the relative structural decline of US power, especially combined with the parallel rise in power of China and the 2008 financial crisis, consecrated the US' fall from its pedestal, and paradoxically improved the favorability of the US in the eyes of ordinary French (Kim, Meunier, \& Nyiri, 2017; Meunier, 2013). At the turn of the 2010 decade, the sources of worries regarding trade and investment came more from China than they did from the US. Second, the election of Barack Obama in 2008 contributed to warming French opinion of the US soaring to a consistent $60 \%$ for much of Obama's two terms. After the election of Donald Trump in 2016, French views of the US dipped back to historically low levels in the 1930s (Figure 5).

While French opinion of the US was warming, a reverse trend took place in Germany, where the revelations of widespread American surveillance by the National Security Agency in 2013 triggered a rise in anti-American sentiment. The German public, wary of surveillance for historical reasons, was incensed after learning from Edward Snowden that the US was routinely monitoring Chancellor Angela Merkel's phone. Further revelations of American spying on Germany in 2014 fuelled German anger, further damaging public perceptions of the US. Thus, while views of the US benefitted from the same 'Obama' windfall in Germany as in France, by the time of the TTIP negotiations, they were much less favourable than the French with a $24 \%$ point difference in 2014 , and 23\% in 2015 (Figure 5). This relative resurgence of anti-Americanism in Germany has been highlighted by several analysts as the principal explanation for the puzzling German mobilization on TTIP (Bauer, 2016; Chan \& Crawford, 2017). We take one step further by showing how political entrepreneurship at the governmental level and at the level of the grassroots underpinned these changing patterns of anti-American sentiments. 


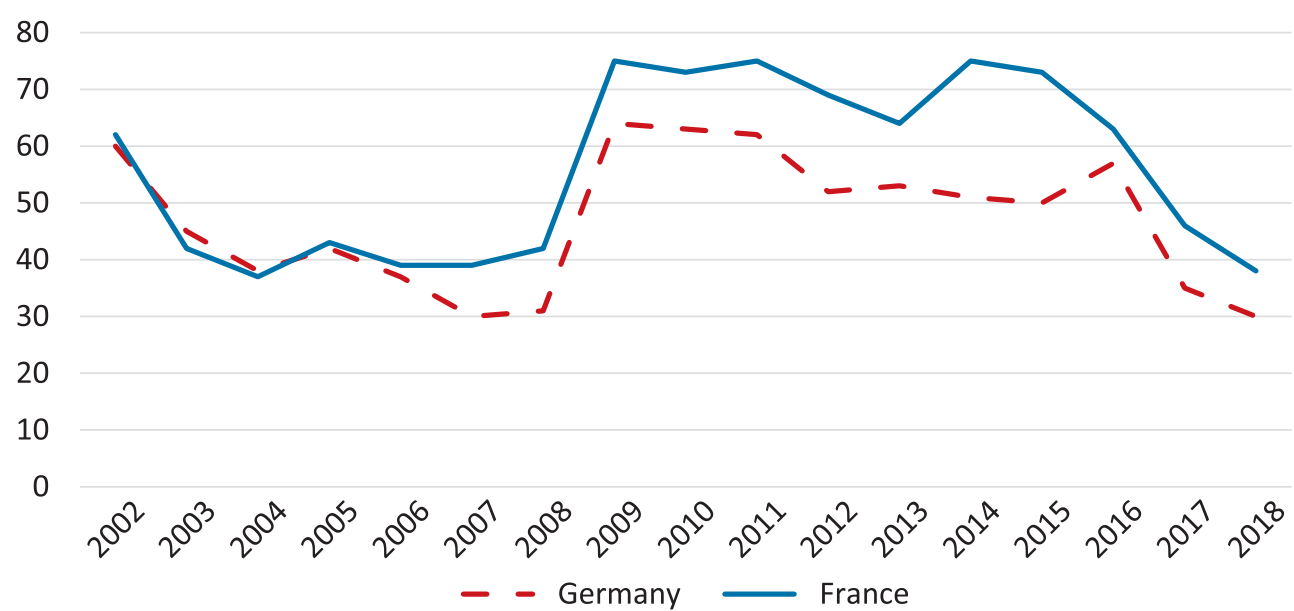

Figure 5. Favourable views of the US in France and Germany 2002-2018 (percentage responding favorable, all years measured). Source: Pew Research Center (2019). Note: Full question wording "Please tell me if you have a very favorable, somewhat favorable, somewhat unfavorable, very unfavorable opinion of the US."

\subsection{Institutional Entrepreneurship: Agenda-Shaping and Venue-Shaping}

Cultural issues had been the unifying focus of French opposition to the MAl across the political spectrum and a focal point in anti-American and anti-globalization sentiments in France. With the TTIP, cultural goods and services came back as a likely bone of contention in the French debate. However, this time, an important part of the French government's strategy was to manage the looming confrontation by shaping the agenda and the venue of the negotiations.

By agenda-shaping, we refer to efforts by the French government to remove the potential lightning rods of mass contention, first and foremost the issue of audiovisual goods and services which had such a cross-cutting character. In its draft mandate of 12 March 2013, the European Commission had not only provided for the inclusion of the audio-visual sector in the negotiations, it also precluded the use of unanimity decision-making in the Council, which applies to these issues in virtue of Article 207 of the Treaty on the Functioning of the EU. The French riposte did not wait. In a report of 29 March 2013, the deputies of the French Assemblée Nationale expressed their outrage, noting that:

It is the first time, in twenty years, that the Commission does not respect the principle of the cultural exception by not explicitly excluding the audio-visual sector from an international trade agreement, a fortiori with the US. This is an unprecedented liberal offensive, which requires a response from the national representatives. (Assemblée Nationale, 2013, p. 2)

The deputies called on the French government to demand that the Commission remove cultural services from the mandate-and to block the text in the Council meeting of 14 June 2013, if necessary, by making use of its veto under unanimity voting. This demand was ini- tially contested in the Commission, where the College of Commissioners had voted in favour of the text, but also in the European Parliament committee on International Trade, where the chair did not favour the cultural exception (Roederer-Rynning, 2017). Eventually, the French offensive succeeded to reverse the tide in the Council and the European Parliament.

In the Council, supported by thirteen other Member States, as well as many prominent European directors, the French government led the drive to specifically remove audio-visual services from the mandate granted to the European Commission to negotiate with the US on behalf of the EU (Ministère de la Culture, 2013). On 16 May 2013, at the Culture and Education Council, 15 Member States signed a letter calling for the exclusion of culture and audio-visual services from the negotiations. This paved the way for a similar reversal to take place in the European Parliament. Less than ten days later, on 23 May 2013, the European Parliament adopted a resolution giving its (not formally binding) support for opening the TTIP negotiations. Critically, the French secured the scheduling of a separate vote on the 'cultural exception,' in the margin of the vote on the resolution. Reflecting active lobbying by the French Socialist delegation in the European Parliament, particularly by Member of the European Parliament (MEP) Henri Weber, the vote garnered a majority in plenary, although with lower levels of support than the overall resolution (381 in favour, 191 against, 17 abstentions on the cultural exception; compared to 460 votes in favour, 105 against, and 28 abstentions on the overall TTIP resolution). Thus, a combination of governmental activism and multi-level parliamentary mobilization (Roederer-Rynning \& Kallestrup, 2017) enabled French delegates to remove audio-visual goods and services from TTIP negotiations, leaving the French government with one less traditional point of contention to worry about.

There were still a host of contentious issues on the agenda, however, one of them being the hotly 
contested ISDS. Compared with 'the cultural exception,' which had a distinctively French resonance, ISDS was more broadly controversial among the Member States; therefore, France did not have to wage the battle against it alone, or even lead the battle. Still, the French government was active on this issue, especially the Junior Minister for International Trade, Matthias Fekl, pre-empting domestic mobilization by fighting against 'Brussels' and demanding that a public consultation be held on ISDS and negotiations be suspended during the consultation. In hindsight, we know that the consultation marked a turning-point not only in the TTIP negotiations (the object of the consultation), but also in the CETA negotiations, where an alternative to the ISDS provision had to be found in order to pass ratification. This was achieved mostly with the help of social movement activists based in other countries than France. The public consultation also acted as a magnet for social mobilization. $80 \%$ of replies came from three Member States: Germany alone accounted for $21.7 \%$ of replies, followed by the UK with $34.8 \%$, and Austria with $22.6 \%$. Among institutional actors, the Assemblée Nationale was one of only three national parliaments contributing to the public consultation, while the other two were the Irish Oireachtas and the Romanian Senate (Roederer-Rynning \& Kallestrup, 2017, p. 818). Thus, ironically, while demanded by France, the consultation served as a platform for social movement activists from other Member States to launch a broad-based critique against the ISDS.

Finally, the French government also sought to defuse massive public contestation by keeping the ratification process of an eventual TTIP agreement under the control of national parliaments via the so-called mixed ratification route. As with the issue of 'cultural exception,' the French had to battle with the Commission, which favored the Treaty of Lisbon's new 'simple ratification' procedure, empowering the European Parliament-not the national parliaments - to ratify free-trade agreements. The government was allied with the Assemblée Nationale, who was adamant that "the transatlantic trade and investment partnership between the EU and the US is a 'mixed agreement' in the sense of EU law, requiring ratification by all the Member States" (Assemblée Nationale, 2013, p. 6). But the issue was moot. The mandate directive contained no clause on the character of the agreement and its ratification status, and the Commission itself, as the parliamentary opposition pointed out, advertised the TTIP on its webpages as a simple agreement (Assemblée Nationale, 2014, p. 3413). In May 2014, when doubts resurfaced, the head of the Foreign Affairs committee in the Assemblée recalled the 'Korea' technique (i.e., used in the EU Free Trade Agreement with Korea) "consisting in inserting a cultural clause in the agreement to make sure it would be ratified as a mixed agreement" (RoedererRynning \& Kallestrup, 2017, p. 821). Later, French state secretary for trade Fleur Pellerin insisted that "this will be a mixed agreement" (Assemblée Nationale, 2014, p. 3409) and cited the support of Germany.
In sum, by defusing the 'cultural exception' issue, the French government fragmented a re-emerging broad-based, culture-focused, cross-partisan opposition to the TTIP, keeping it effectively within narrower partisan bounds. Furthermore, by calling for a public consultation on ISDS, the government sat the negotiations on standby while offering a platform for social movement entrepreneurs across Europe to rally against the ISDS. Finally, France acted in coordination with Germany and its own parliament to keep the mixed ratification format. The government's active management strategy placed France in a more comfortable position than other Member States (Xavier-Bender, 2015, p. 2). This contrasted with the much more precautionary and passive stance adopted by the German government-overwhelmed by unexpected levels of societal resistance.

\subsection{Social Movement Entrepreneurship: Changes in ATTAC and the Pivotal Role of the Social Media}

The relatively low social mobilization of the French public on TTIP could very well reflect the exceptional circumstances of 2015-2016. The anti-trade and investment protests in Europe coincided with the most dramatic wave of terror attacks perpetrated in France in recent times. In 2015, 20 people died in Paris as a result of the Islamic terrorism attacks on the French satire weekly Charlie Hebdo, followed by a series of terrorist attacks in November, killing 137 people during assaults on the Bataclan theatre and the Stade de France. In 2016, 87 people were killed by a terrorist truck attack in Nice on Bastille Day. Thus, after January 2015, the collective will and psyche in France were occupied elsewhere. Arguably, the French were too worried about domestic terrorism to fuss about TTIP, and perhaps too shocked to participate in public demonstrations.

Even so, while terror might have overshadowed the trade agenda, the altermondialiste movement in France in the 2010s was a pale reflection of itself. No strong movement entrepreneur emerged in France during the time of the TTIP negotiations. Though ATTAC was, once again, at the forefront of the contestation and public mobilization against TTIP, ATTAC France no longer played the role it once did in the heyday of the movement at the turn of the 21st century. Mired in scandals and infighting, ATTAC France saw its membership drop by twothirds in the first half of the 2000s (Stockemer, 2012). The organization had also lost its most charismatic member. By the time the TTIP negotiations came along, Bové had become part of the system himself. After an unsuccessful run for the French presidency in 2007, he was elected MEP under the banner of the Green party Europe Ecologie and was re-elected in 2014. While still involved in civil disobedience and media-grabbing actions, Bové was mostly exerting his policy influence through his work in the European Parliament. By contrast, German ATTAC had become quite prominent, with a membership jump 
from 2,000 members in 2001 to 23,000 in 2009, and ample coverage in German media (Stockemer, 2012).

German activists also brought mobilization to new heights by mastering the art of social media campaigning. The TTIP negotiations generated intense engagement from public media from the outset. Already in 2013, communication specialists in the European Commission were "alarmed" by what a leaked Commission paper called the "unprecedented level of public and media interest" (von Nordheim, Boczek, Koppers, \& Erdmann, 2018 , p. 549). The importance of social media was considerable: tweets containing \#ttip tended to be dominated by NGOs and groups of activists. They tended to be more driven by global anti-TTIP sentiments, and less connected to national discourses and grievances, in contrast to printed news in traditional media (von Nordheim et al., 2018, p. 562). Over time, "the sentiment of [the TTIP-related] discussion on Twitter [became] more polarized and less balanced" (von Nordheim et al., 2018, p. 561). Remarkably, there were important national differences in this regard, too. Only in Germany and in the Netherlands did \#ttip make it on the top-10 list of trending hashtags (Nulty, Theocharis, Popa, Parnet, \& Benoit, 2016). In Germany alone, \#ttip was more popular than in any other European country, ranking second on the top-10 list, just behind \#piraten. In contrast, in France, the TTIP negotiations were much less salient in the social media, and mostly so under the more insular \#tafta. These results confirm claims that "the rise of the Internet and social media has boosted the public salience of EU trade policy...forcing transparency, enabling expertise, shaping public opinion, and facilitating tools for mobilization" (Meunier \& Czesana, 2019, p. 9).

\section{Conclusion: The Double Movement of Contentious Trade Politics in Europe}

In the emerging literature on the politicization of trade policy, the TTIP stands out by the level of public contestation it generated in Western democracies. In the established comparative European politics literature on collective action and social movements, France stands out by the contentiousness of its society. Yet France and its activists surprisingly did not play a leading role in the broad public mobilization that shook Europe during the TTIP negotiations. Unlike their German counterparts, ordinary French long ignored the TTIP and were agnostic about its potential implications. They did not care enough to protest massively and durably against it. In 2015 Europe, the contentious Europeans were German, not Frenchwhy this double movement?

Using a combination of historical and cross-national comparison, we have put forward a political process explanation combining anti-Americanism ideas, institutional entrepreneurship, and social movement entrepreneurship. The key to understanding why Germany and France swapped places in the politicization of trade in the 2010s is how political entrepreneurship at the gov- ernmental and societal level shaped anti-Americanism in these societies. In France, a country that had much to gain from the TTIP given the sluggishness of its economy at the time, the government prevented the formation of a broad-based cross-cutting popular movement by first removing cultural issues from the agenda through multi-level institutional lobbying, then fighting for the mixed ratification of an eventual TTIP agreement-with Germany, and lastly de facto outsourcing protest against ISDS to other European countries (Germany), while suspending the negotiations through the European public consultation organized upon its request. These actions stand in sharp contrast with the more precautionary and passive stance adopted by the German governmentoverwhelmed by unexpected levels of societal resistance and a newly-blossoming variety of anti-Americanism. Consequently, not only was the French government in a much more comfortable position than other Member States; it could, and did, hide behind the turbulent German politics.

At the societal level, an important and overlooked mutation in the infrastructure of the anti-globalization social movement took place during these years in Europe. This is captured by the changing centre of gravity of ATTAC. ATTAC Germany did for the politicization of trade in the 2010s what ATTAC France did in the 1990s, although through other means. While the French precursors' contribution was to build an intellectual infrastructure for the anti-globalization movement-or altermondialiste-the new generation of German activists brought the anti-globalization movement to new heights by mastering the art of social media campaigning.

Our study contributes to the scholarship in several ways. First, it highlights the enduring role of culture in anti-trade mobilization. Culture is a glue binding together various segments of the citizenry above generational, partisan, and socio-economic cleavages-it is therefore a powerful force of mobilization. However, cultural resistance is politically constructed: it can be fuelled and defused by political leaders and movement entrepreneurs. Second, contemporary Europe displays the coexistence of an old and new politics of trade. In the old politics of trade, producers protest the opening of markets and demand protection. This was traditionally the case of farmers' demonstrations in France. In the new politics of trade, precautionary consumers and citizens protest the interference into domestic regulation of public norms and standards arising from diffuse, non-elected international bodies. Occasionally, like in France, the old politics could transcend the narrow bounds of its producer basis by appealing to culture. The new politics of trade, by contrast, is by definition mass politics, in virtue of its broader societal basis and proneness to cultural exploitation.

Looking towards the future and the likely resumption of some more modest trade talks between the EU and the US, we speculate that the TTIP period may have been a unique moment of opportunity in France unlikely to re- 
peat itself soon. Domestically, the French government is again on the defensive, with the Gilets Jaunes mobilization since late 2018 against the background of the neoliberal socio-economic reforms undertaken by Macron, which could easily morph into opposition against international trade agreements. Internationally, the protectionist turn and overall nationalist agenda of the Trump administration, coupled with German power in relative decline in Europe, mean that the French can no longer ignore their long-standing mistrust of the US, nor hide behind Germany, setting the stage for a more open and assertive confrontation. This will make it more difficult to carry out a liberalizing transatlantic agenda, unless the rise of China serves as a glue forcing European and American interests to converge.

\section{Acknowledgments}

We wish to thank the Academic Editors, Alan Matthews, and reviewers for their comments on an earlier version of the article. Thanks also to the participants and audience of the panel on 'Politicization and EU Trade Policy' at the EUSA conference in Denver, where the idea for this article was born, and to Anna Vlasiuk for research assistance and Lauren Konken for editing. Support for this research was provided by the Princeton-Sciences Po EUROGLOB grant. Finally, our thanks go to the EU and French policymakers and scholars who accepted to be interviewed anonymously for this research project-merci!

\section{Conflict of Interests}

The authors declare no conflict of interests.

\section{References}

Alons, G. (2014). Farmers versus ideas: Explaining the continuity in French agricultural trade policy during the GATT Uruguay round. Journal of European Public Policy, 21(2), 286-302. https://doi.org/10.1080/ 13501763.2013.836055

Alons, G., \& Giacalone, R. (2014). Anti-Americanism and trade policy in Brazil and France. Iberoamericana: Nordic Journal of Latin American and Caribbean Studies, 43(1/2), 145-168. http://doi.org/10.16993/ ibero. 26

Ancelovici, M. (2002). Organizing against globalization: The case of ATTAC in France. Politics \& Society, 30(3), 427-463. https://doi.org/10.1177/ 0032329202030003003

Assemblée Nationale. (2013). Proposition de résolution européenne relative au respect de l'exception culturelle [Proposal for a European resolution on the respect of cultural exception]. Assemblée Nationale. Retrieved from http://www.assemblee-nationale.fr/ 14/propositions/pion0875.asp

Assemblée Nationale. (2014, May 22). Compte-rendu intégral: No. 48 [Report Session No. 48]. Assemblée
Nationale. Retrieved from http://www.assembleenationale.fr/14/cri/2013-2014/20140212.asp

Barkin, N. (2015, April 18). Thousands in Germany protest against EU-US Trade Deal. Reuters. Retrieved from https://www.reuters.com/article/us-tradeprotests-germany/thousands-in-germany-protestagainst-europe-u-s-trade-deal-idUSKBNON9OLO20 150418

Bauer, M. (2016). The political power of evoking fear: The shining example of Germany's anti-TTIP campaign movement. European View, 15(2), 193-212. https:// doi.org/10.1007/s12290-016-0424-4

Bluth, C. (2016). GED study: Attitudes to global trade and TTIP in Germany and the United States. Gütersloh: Bertelsmann Stiftung.

Bouza, L., \& Oleart, A. (2018). From the 2005 Constitution's 'permissive consensus' to TTIP's 'empowering dissensus': The EU as a playing field for Spanish civil society. Journal of Contemporary European Research, 14(2), 87-104. https://doi.org/10.30950/ jcer.v14i2.862

Buonanno, L. (2015). The TTIP arrives: Politics and proccesses. In L. Buonanno, N. Cuglesan, \& K. Henderson (Eds.), The new and changing transatlanticism: Politics and policy perspectives (pp. 235-258). Abingdon: Routledge.

Caiani, M., \& Graziano, P. (2018). Europeanisation and social movements: The case of the stop TTIP campaign. European Journal of Political Research, 57(4), 1031-1055. https://doi.org/10.1111/14756765.12265

Chan, A. T., \& Crawford, B. K. (2017). The puzzle of public opposition to TTIP in Germany. Business and Politics, 19(4), 683-708. https://doi.org/10.1017/bap. 2017.32

CSA. (2014, May 20). Les Français et le Traité Transatlantique de Libre-Échange [The French and TTIP]. CSA. Retrieved from https://www.csa.eu/media/ 1209/opi20140514-les-francais-et-le-traitetransatlantique-de-libre-echange.pdf

De Bièvre, D., \& Poletti, A. (2017). Why the transatlantic trade and investment partnership is not (so) new, and why it is also not (so) bad. Journal of European Public Policy, 24(10), 1506-1521. https://doi.org/ 10.1080/13501763.2016.1254274

De Bièvre, D., \& Poletti, A. (2019). Explaining varying degrees of politicization of EU trade agreement negotiations: On necessary and sufficient conditions. Paper presented at the Biennial Conference of the European Union Studies Association (EUSA), Denver, CO.

De Bruycker, I. (2017). Politicization and the public interest: When do the elites in Brussels address public interests in EU policy debates? European Union Politics, 18(4), 603-619. https://doi.org/ $10.1177 / 1465116517715525$

De Ville, F., \& Siles-Brügge, G. (2015). TTIP: The truth about the Transatlantic Trade and Investment Partnership. Polity Press: Cambridge, MA. 
de Wilde, P. (2011). No polity for old politics? A framework for analyzing the politicization of European integration. Journal of European Integration, 33(5), 559-575. https://doi.org/10.1080/07036337. 2010.546849

Deckstein, V. D., Salden, S., \& SchießI, M. (2016, May 6). Protests threaten trans-Atlantic trade deal. Spiegel International. Retrieved from https://www.spiegel.de/ international/world/protest-movement-threatensttip-transatlantic-trade-deal-a-1091088.html

Deslauriers, J., \& Kotschwar, B. (2003). After Seattle: How NGOs are transforming the global trade and finance agenda. In J. P. Doh \& H. Teegen (Eds.), Globalization and NGOs: Transforming business, governments, and society (pp. 35-64). Westport, CT: Praeger Books.

Donnan, S. (2016, September 22). Free-trade v populism: The fight for America's economy. Financial Times. Retrieved from https://www.ft.com/content/ 9f558874-7fe2-11e6-8e50-8ec15fb462f4

Eliasson, L. J., \& Garcia-Duran Huet, P. (2019). Civil society, rhetoric of resistance, and transatlantic trade. Berlin: Springer International Publishing.

Euractiv. (2015). Anti-TTIP petitions signed by 3 million people. Euroactiv. Retrieved from https:// www.euractiv.com/section/agriculture-food/news/ anti-ttip-petition-signed-by-3-million-people

Eurobarometer. (2014). Standard Eurobarometer 82 (Autumn 2014 Report). Brussels: European Commission.

Eurobarometer. (2015a). Standard Eurobarometer 83 (May 2015 Report). Brussels: European Commission.

Eurobarometer. (2015b). Standard Eurobarometer 84 (May 2016 Report). Brussels: European Commission.

Eurobarometer. (2016). Standard Eurobarometer 85 (Autumn 2014 Report). Brussels: European Commission.

Fabry, E. (2015, June 10). La France: Un terreau d'opposition au TTIP? [France: A fertile ground for opposition to TTIP?] (Policy Paper No. 136). Paris: Institut Jacques Delors.

Gordon, P. H., \& Meunier, S. (2001), Globalization and French cultural identity. French Politics, Culture \& Society, 19(1), 22-41. https://www.jstor.org/stable/ 42843147

Graham, E. M. (2000). Fighting the wrong enemy: Antiglobal activists and multinational enterprises. Washington, DC: Peterson Institute for International Economics.

Kim, S. Y., Meunier, S., \& Nyiri, Z. (2017). Yin and yank? Public opinion in Europe toward the U.S. and China. Comparative European Politics, 15(4), 577-603. https://doi.org/10.1057/s41295-016-0005-6

Kobrin, S. J. (1998). The MAI and the clash of globalizations. Foreign Policy, 112, 97-109.

Kolb, F. (2005). The impact of transnational protest on social movement organisations: Mass media and the making of ATTAC Germany. In D. Della Porta \& S. Tarrow (Eds.), Transnational protest and global activism (p. 95-199). Lanham, MD: Rowman and Littlefield.
Lalumiere, C., \& Landau, J. P. (1998, October 23). Rapport sur l'Accord Multilatéral sur l'Investissement (AMI) [Report on the Multilateral Agreement on Investment (AMI)]. Retrieved from http://www. assembleenationale.fr/europe/rap-info/2fdi1150.pdf

Lamy, P. (2014, October 27). Transatlantic trade negotiators should own up to their ambition. Financial Times. Retrieved from https://www.ft.com/content/ d69d4496-5a07-11e4-8771-00144feab7de

Laursen, F., \& Roederer-Rynning, C. (2017). Introduction: The new EU FTAs as contentious market regulation. Journal of European Integration, 39(7), 763-779. https://doi.org/10.1080/07036337.2017.1372430

Meunier, S. (2000). The French exception. Foreign Affairs, 79(4), 104-116.

Meunier, S. (2006). The distinctiveness of French antiAmericanism. In P. J. Katzenstein \& R. O. Keohane (Eds.), Anti-Americanism in world politics (1st ed., pp. 129-156). Ithaca, NY: Cornell University Press.

Meunier, S. (2013). The dog that did not bark: Antiamericanism and the 2008 financial crisis in Europe. Review of International Political Economy, 20(1), 1-25. https://doi.org/10.1080/09692290.2011. 649674

Meunier, S., \& Czesana, R. (2019). From back rooms to the street? A research agenda for explaining variation in the public salience of trade policy-making in Europe. Journal of European Public Policy, 26(12), 1847-1865. https://doi.org/10.1080/13501763. 2019.1678058

Ministère de la Culture. (2013, May 14). Exception culturelle: La France n'est pas seule! [Cultural exception: France is not alone!] [Press release]. Retrieved from https://www.culture.gouv.fr/Presse/ArchivesPresse/Archives-Communiques-de-presse-20122018/Annee-2013/Exception-culturelle-la-Francen-est-pas-seule

Mobilisations. (2016). Stop-TAFTA. Mobilisations. Retrieved from https://stoptafta.wordpress.com/ mobilisations

Nulty, P., Theocharis, Y., Popa, S. A., Parnet, O., \& Benoit, K. (2016). Social media and political communication in the 2014 elections to the European Parliament. Electoral Studies, 44, 429-444. https://doi.org/ 10.1016/j.electstud.2016.04.014

Pew Research Center. (2019). Opinion of the United States: Do you have a favorable or unfavorable view of the U.S.? Pew Research Center. Retrieved from https://www.pewresearch.org/global/database/ indicator/1

Roederer-Rynning, C. (2002). Farm conflict in France and the Europeanisation of agricultural policy. West European Politics, 25(3), 105-124. https://doi.org/ 10.1080/713601616

Roederer-Rynning, C. (2007). Farm conservatism in France: Revisiting the weak state thesis. Journal of European Public Policy, 14(7), 1010-1027. https:// doi.org/10.1080/13501760701576502 
Roederer-Rynning, C. (2017). Parliamentary assertion and deep integration: The European Parliament in the CETA and TTIP negotiations. Cambridge Review of International Affairs, 30(5/6), 507-526. https:// doi.org/10.1080/09557571.2018.1461808

Roederer-Rynning, C., \& Kallestrup, M. (2017). National parliaments and the new contentiousness of trade. Journal of European Integration, 39(7), 811-825. https://doi.org/10.1080/07036337.2017.1371710

Schimmelfennig, F., Leuffen, D., \& Rittberger, B. (2015). The European Union as a system of differentiated integration: Interdependence, politicization and differentiation. Journal of European Public Policy, 22(6), 764-782. https://doi.org/10.1080/13501763. 2015.1020835

Stockemer, D. (2012). The importance of group identity processes in involvement in social movement organizations: The case of ATTAC France and Germany. Innovation: The European Journal of Social Science Research, 25(3), 268-282. https://doi.org/10.1080/ 13511610.2012.703830

Tartaglione, N. (1998). France's left and right join to blast international treaty. Variety, 370(8), 6-12.

TTIP Free Zones. (n.d.). TTIP free zones Europe. TTIP Free Zones. Retrieved from https://www.ttip-free-zones. eu

van der Vleuten, A., \& Alons, G. (2012). La grande nation and agriculture: The power of French farmers demystified. West European Politics, 35(2), 266-285.

Von Nordheim, G., Boczek, K., Koppers, L., \& Erdmann, E. (2018). Reuniting a divided public? Tracing the TTIP debate on twitter and in traditional media. International Journal of Communication, 12, 548-569.

Vu de France. (2016, August 5). A propos du CETA: Quand les parliamentaires prennent les citoyens pour des cons [Regarding CETA: When representatives take citizens for fools]. Stop-TAFTA. Retrieved from https:// stoptafta.wordpress.com/category/vu-de-france

Wagstyl, S. (2016, April 28). Anti-Americanism fuels German fears over TTIP trade pact. Financial
Times. Retrieved from https://www.ft.com/content/ 7c8100e8-0b99-11e6-9456-444ab5211a2f

Walter, A. (2001). NGOs, business, and international investment: The Multilateral Agreement on Investment, Seattle, and beyond. Global Governance, $7(1)$, 51-73.

Waters, S. (2004). Mobilising against globalisation: ATTAC and the French intellectuals. West European Politics, 27(5), 854-874. https://doi.org/10.1080/ 014023804200028329

Wood, D. (2000). The international campaign against the Multilateral Agreement on Investment: A test case for the future of globalisation? Philosophy and Geography, 3(1), 25-45. https://doi.org/10.1080/ 13668790008573692

World Trade Institute. (2016). TTIP and the EU member states: An assessment of the economic impact of an ambitious Transatlantic Trade and Investment Partnership at EU member state level. Bern: World Trade Institute. Retrieved from https://www.wti.org/ media/filer_public/03/b8/03b803d4-e200-48419c58-f6612f4a7316/ttip_report_def.pdf

Xavier-Bender, G. (2015). France's unexpected role on the way to a reasonable and balanced TTIP (Policy Paper No. 2). Washington, DC: German Marshall Fund.

YouGov. (2015, April 20). Americans and Europeans ambivalent about free trade. YouGov. Retrieved from https://d25d2506sfb94s.cloudfront.net/cumulus_ uploads/document/8h6hq2m8mr/March_ Eurotrack_Website.pdf\#page $=2$

Young, A. R. (2017). The new politics of trade: Lessons from TTIP. New York, NY: Columbia University Press.

Young, A. R. (2019). Two wrongs make a right? The politicization of trade policy and European trade strategy. Journal of European Public Policy, 26(12), 1883-1899. https://doi.org/10.1080/13501763.2019.1678055

Young, A. R., \& Peterson, J. (2006). The EU and the new trade politics. Journal of European Public Policy, 13(6), 795-814. https://doi.org/10.1080/ 13501760600837104

\section{About the Authors}

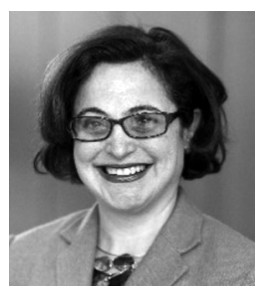

Sophie Meunier is Senior Research Scholar in the Woodrow Wilson School of Public and International Affairs at Princeton University and Co-Director of the EU Program at Princeton. She is the author of Trading Voices: The European Union in International Commercial Negotiations (2005) and The French Challenge: Adapting to Globalization (2001), as well as Editor of several books on Europe and globalization. Her current work deals with the politics of Foreign Direct Investment in Europe, notably Chinese investment.

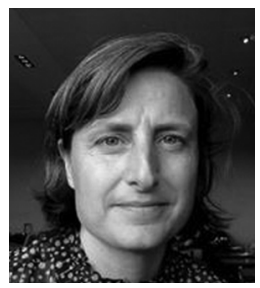

Christilla Roederer-Rynning is Professor with special responsibilities in Comparative European Politics. She works on EU policy-making, the Common Agricultural Policy, and trade policy. She coordinated a research project on 'The Parliamentarization of EU Politics,' financed by the Danish Council for Independent Research. She is the Co-Editor of Policy-Making in the European Union (8th ed.), with Helen Wallace, Mark Pollack, and Alasdair Young (Oxford University Press, in press). 